\title{
Conceptualising Teachers' Work in a Uniting Europe
}

\author{
RONALD G. SULTANA, University of Malta
}

\section{Introduction}

In this article I would like to situate teachers' work-defined, following Ozga \& Lawn (1988), in terms of the labour and social process of teaching-within wider economic, political and cultural contexts. The reference to "a uniting Europe" in the title of this article links in with my current research agenda in response to my country's application to join the European Union. Despite this specificity, I will argue that the European context which defines the work of close to 5 million teachers (Andrieu, 1992) is not that different from other contexts, be these North American or Australian. Such a claim is possible given the overwhelming evidence of what Giddens (1989) refers to as the "globalizing of social life", where we can now speak of "forms of social association which span the earth". "The world", argues Giddens, "has become in important respects a single social system, as a result of ties of interdependence which now virtually affect everyone. The global system is not just an environment within which particular societies ... develop and change. The social, political and economic connections which cross-cut borders between countries decisively condition the fate of those living within each of them" (Giddens, 1989, pp. 519-520).

The specific focus of the article should provide, therefore, a case-study of how processes in one of the world's major economic blocs affect the work of teachers. For, as will be argued below, despite differences between countries, the emerging global economy virtually demands that nations address similar educational issues (Guthrie \& Pierce, 1990), and that the teaching body internationally faces the same kind of challenges (Watson, 1991).

Given the kind of arguments I would like to make in the subsequent sections, and my belief in understanding as a precondition for self- and group-empowerment, it is important that I pursue the point about globalisation further. For it is crucial for teachers to appreciate the roots and dynamics of the social organisation of forms of life which they are currently experiencing if they are to identify common foes and co-ordinated strategies of resistance, attack and counter-attack. The context which frames such processes and such battles - for battles they are-are no longer national units, those pillars of modern society which arose in the 15th century, and which were upheld by the school, the army and the factory (Kurth, 1993, p. 8). Rather, the post-modern world, while still containing old states, is increasingly becoming re-organised along multina- 
tional non-state lines (Kurth, 1993, p. 13). As Featherstone (1991, p. 146) has argued, "the increased international flows of money, goods, people, images and information have given rise to 'third cultures', which are transnational and mediate between national cultures". The deconstruction of the "old" modern world and its reconstruction into new forms and new organisations which are not states-the European Union, international organisations, international law, global financial markets, multinational enterprises, and global media-presents new challenges for educators, as we search for our identity, for answers and for a vocation in a world marked by economic, political and cultural internationalisation. To fail to think through such issues not only places us on the defensive, in a situation where piecemeal responses to agendas set elsewhere are the order of the day. It also condemns us to a spectator role as the latter-day Charlemagnes carve out new empires and erect new belief systems, while we watch and wait.

\section{The International Economic Context and Education}

Globalisation is only one of the more important economic trends which currently frame and contextualise our work as teachers. Several political economists of education have identified a number of broad principles which organise today's world, and which will be felt by teachers in their classrooms and schools as specific pressures to be and act in specific ways rather than others. Levin (1990), for instance, identifies the intensification of reliance on innovatory technology as well as the restructuring of the workplace-both within the context of a new impetus for internationalisation-as crucial elements in the definition of the tasks of teaching and a vision for education in the post-modern world.

Guthrie \& Pierce (1990) point out similar trends in the formation of a multinational, interdependent network economy where governments, used to a situation where decisions were almost exclusively based on domestic political considerations, are now realising that "trade balances, monetary regulation, interest rates, capital flows, productivity enhancement, economic growth, employment levels, and living standards are ... internationally linked" (Guthrie \& Pierce, 1990, p. 180). In this situation of economic competition and commercial co-operation in a context of depressed markets, most industrialised nations face a similar set of policy problems which ultimately affect the general approach to the question of education. Among these problems are the challenge of enhancing economic productivity, the induction of scientific inventions and technology transfer, the upgrading of work force capability, the overcoming of bureaucratic inertia, the change of public attitudes and habits, and the balancing of competing claims for national resources (Guthrie \& Pierce, 1990).

This scenario is presently being played out in Europe as much as in Australia or North America, and the key players are, perhaps more than ever before, incredibly powerful owners of capital who associate and collude in search of their interests in activities which know no national barriers. Let us look at the way these processes are evolving in that newest of "imagined communities" (Anderson, 1982), the EU.

As an economic space or bloc, the aspirations of a Single Market which facilitates the free flow of capital, goods, persons and services represents the offensive of a capitalist class in the face of international competition, mainly from North America and the Pacific Rim. As Ross (1992, p. 65) has pointed out, "struggle over the future of Europe is largely about developing more promising environments for capitalist success", even if the formulation of new options is being carried out by political entrepreneurs.

Based on the assumptions of orthodox market economics, which, with the routing of alternative forms of social arrangements to capitalism, are generally accepted as 
self-evident truths, the removal of administrative, technical and other non-tariff barriers are thought to reduce costs, increase competition, enhance economic activity and deal with that most terrible of enemies, stagflation (Ross, 1992, p. 53).

In generating such a momentum, capitalists make their presence felt, and to a large degree set the agenda. Ramsay (1992, p. 25) for instance, refers to the extraordinary influence wielded by the Round Table of European Industrialists - made up of twelve major companies operating chiefly in the information technology area-in the lobbying for "European market integration to be completed as a prerequisite for the formation of Euro-companies capable of meeting the challenge from abroad". "The fact", notes Ramsay, "that this group include[s] many of the largest, most successful and most influential companies in the region signall[s] the coincidence of the Commission's strategy and the interests of international capital with a European base" (p. 25).

In such a scenario, Labour movement objectives such as the preservation of jobs can hardly be fulfilled. As Ross (1992, p. 56) notes, Europe has seen a severe weakening of labour due to rising unemployment and capital's restructuring efforts. Indeed, from the point of view of some of the representatives of the social democratic left in Europe, there is a fear that the project of a united Europe will set new limitations on the national economic-political scope for action, especially in such areas as the maintenance of a welfare state. It is also feared that the project will change the relative strength of capital and labour in favour of the former, and will lead to a downward spiralling of wages and social standards as different EU member states attempt to provide the most attractive packages for mobile capital (Haahr, 1992, pp.79,80). The European Trade Union Council, for instance, expressed its fear that the harmonisation of workers' rights in the then EC's social contract will take place according to the principle of the lowest common denominator (ETUC conference, May 1988, cited in Haahr, 1992 p. 91).

\section{Education}

Capitalist influence does not stop in the field of economic decision-making, but permeates the political and ideological fields as well. While state theory has moved us away from the reductionist and essentialist positions of the early Marxists, who were wont to see the state as the executive committee of the class in power, there is nevertheless a congruence between the interests of capital and the restructuring of the educational field. With reference to most European and other education systems, capitalist strategy has, for the past decade and a half, been predictably vocationalist, utilitarian, and managerial-a not unexpected or unique offensive in the history of education within a capitalist context. As Carnoy \& Levin (1985) have pointed out, it is during periods of crisis of capital accumulation that education-and teachers-have generally been taken to task for failing to produce workers with adequate technical, cognitive, and attitudinal skills.

In the current economic crisis, governments have been only too ready to export the blame for failure onto education, and all of us, despite the unique histories of our school systems, have experienced the results of the restructuring of educational policies and priorities away from the concerns of the sixties and early seventies (Husén et al., 1992). Sharp (1988, p. 204) gives a list of the new directions in the educational field, including: a growing trend towards centralised control, attacks on the social wage affecting both the amount and direction of educational expenditure, the accentuation of hierarchical and horizontal divisions within education, a greater emphasis on vocationalism and instrumentalism, moves towards the commodification and privatisation of education, curricu- 
lum differentiation, an intensification of the competitive ethos, the impregnation of education with market and management discourse (Sharp, 1988, p. 204). Current comparative educational literature provides ample research evidence to bear Sharp's point that these new directions work in the interest of some groups, and are "disastrous for precisely those groups who formed the target of the earlier social democratic advances: working class pupils, women, the disabled, migrants or guest workers" (p. 205).

It is worthwhile to delve a bit deeper here, to explore why this is happening. Surely it is not unreasonable for governments to expect education to play a part in the regeneration of the economy? The key issue here is that the relationships between education and the economy have been problematised by some of the most profound thinkers in the field of political economy of education from the sixties onwards. Human capital theory, developed systematically in the 1950s (Violas, 1981; Sultana, 1992), had argued that education provides people with the skills to develop and manage the economy, and that therefore investment in education is an investment in the productive capacity of people. That kind of equation is very attractive to governments who have to legitimise spending on education in a period of economic recession, and who find schools and teachers handy scapegoats in their bid to explain away complex economic problems. In such a situation, one can understand why the approach to education becomes increasingly technocratic, even though there is a lot of evidence to back up labour market segmentation theory, which, in contrast to human capital theory, proposes that "productivity is an attribute of jobs, not of people", and that "people are matched to jobs by criteria which may be associated with education, but education is not a determinant of productivity" (Jamieson, 1989, p. 70).

Much of the current policy-makers' approach to the linkage between education and the economy remains, however, simple to an extreme. The correspondence principle in many of the member states of the European Union, for instance, goes something like this: since it is believed that future economic growth is heavily dependent on the establishment of an effective international orientation to business firms, an orientation reliant to a great extent upon the international knowledge and orientation of employees, then education must prepare the young to understand other cultures and to learn at least one other European language. Since innovatory technology is today's pot of gold, then national curricula must specify an increased focusing on mathematics, science and technology. Since high-technology industries require a highly skilled worker, then the student must be considered as a human resource to be developed in line with economic profiles, and to be moulded into the flexible, adaptable worker required by industry. The new post-fordist European worker, is required to be participative, creative, communicative, proactive, a generalist rather than a specialist, ready and able to work in teams, to solve problems, to plan, reason, and learn on the job. From this, as will be argued in more detail further on, it follows that school environments must change to facilitate the development of this new worker. In line, therefore, with reforms suggested for the administration of the public services more generally, performance tests become introduced for accountability purposes, with performing schools being rewarded and others punished (Ball, 1993). The emphasis on quality in teaching is redefined in terms of results. Operational decision-making is devolved to the school site (Guthrie \& Pierce, 1990 , p. 202).

This, it is thought, will make Europe competitive. As Husén and his colleagues note (1992, p. 7), reporting on the key trends emerging in schooling in modern European society, there is the assumption that "the high economic performance of the Asian 'Dragons' may be explained, at least in part, as an outcome of an efficient school 
system". The corollary to this, for many governments in Western Europe comparing themselves to Japan, is that "underinvestment in skill formation and low school performance in particular, may be factors of importance in an explanation of unfavourable economic performance". Since the perception is that "in industrial manufacturing generally, the countries of the Pacific Rim as a whole may eventually outstrip Europe in competitiveness", then it follows "that this is a material challenge that education in Europe may have to meet" (Husén et al., 1992, p. 7).

Education has not, strictly speaking, been a key official concern of the European Union, though Jean Monnet's cryptic statement with reference to his attempts at getting the EEC going, claiming "If I had to do it again, I would start with education", is frequently cited. In any case, the trade and economic issues of the European Union, "however narrowly defined initially ... ultimately connect to a wide range of other matters and initiate a snowball effect towards greater supranationality" (Ross, 1992, p. 51). Action programmes in education have been devised with funding from the EU with the underlying premise that "there is a causal relationship between the quality and level of ... education and training provision and the efficiency of the economy" (Lowe, 1992, p. 582). The Treaty of Rome and the Single European Act stress that the key objective of education is to strengthen the scientific and technological basis of European industry and to facilitate its international competitivity (Act VI, art. 24). Vocational training, though increasingly seen to be based, given the requirements of post-fordism, on a good general education, is uppermost in the European Union's agendas. The Treaty of Maastricht, for instance, re-affirms the Union's commitment to the establishment of equivalence between certification, in order to facilitate the provision of mobile human resources for capital. Article B para. 2 of the Treaty also formally encourages linkages between industry and education and training systems. This is not at all different from what is happening in North America or Australia, for instance, with the difference that a highly sophisticated network of information about education systems and policies has been set up in the European Community, with the view of "developing exchanges of information and experience on issues common to the education systems of the Member States" (Treaty of Maastricht, Chapter 3, article A, para. 2). This has fanned hopes of utilising educational Europe as a "rich thesaurus of case studies, ready for exploitation" (Bruce, 1991, p. 170). While the European Union emphasises the autonomy of member states in most matters related to education, increasingly European ministers of education meet to discuss the same situations and preoccupations, aim at the same goals, follow similar directions, and adopt similar policies (Leclerq \& Rault, 1989, p. 147; Bouchez \& de Peretti, 1990; Vonk, 1991).

\section{Implications for Education and Teachers' Work}

It has been argued thus far that education, in the European Union and elsewhere, is increasingly considered to be a crucial element in the revitalisation of the economy. The implications of this for education and teaching are not necessarily all negative. For instance, concern with higher achievement levels in education has led to European action programmes geared at the better integration of children of migrants and of gypsies, and students with handicaps and with special learning needs in schools. Other action programmes, similarly organised by the Task Force for Human Resources, Education, Training and Youth have aimed at the better representation of female students in scientific and technical courses. Generally speaking, most of the activities of the European Commission have contributed to the fight against school failure, and have 
placed a premium on the development of attractive pedagogies on the part of teachers, to attract, retain and facilitate the success of students in schools (Vaniscotte, 1989).

More generally, the changing economic conditions could suggest a new agenda for education, one that is not contradictory to the search for social justice and democratic renewal. It is argued by the likes of Pratzner (1986) and Brown \& Lauder (1991) that post-fordist economies have shifted us away from a mechanistic, technological and scientific management perspective of work to a high worker involvement, marked by flexible production, flatter hierarchies, an adaptable and highly skilled workforce, and offering tasks which encourage the breakdown of the division between mental and manual labour and learning. The fast pace of change, new work designs and the growth of knowledge calls not for docility, passive obedience and ability in narrowly defined technical skills but rather for creativity, flexibility, and the ability to learn. In this scenario, therefore, morality has become pragmatic, and there need no longer be a contradiction between educational ideals and the requirements of the economy. Brown and Lauder argue against the assumption that the only viable capitalist economy is one characterised by low wages and low technology, and argue in favour of what they call a "high ability, high wage" society. Schools and teachers will provide the intellectual, technical and creative resources required to achieve sustainable economic growth, and will help to empower people individually and collectively to confront challenges presented by rapid transformation of existing patterns of social and economic life (Brown \& Lauder, 1991, p. 14).

Given the present social climate, such arguments are bound to appear attractive. Criticisms of the "free market" and of the encapsulation of education within that discourse will tend to appear irresponsible unless they are accompanied by a viable strategy for economic renewal (Brown \& Lauder 1991, p. 4). Such views, however, remain problematic. First of all, the technical assumptions on which such arguments are based seem to be flawed. There is a consensus among a large number of economists "that information technology will not produce large numbers of high tech jobs in either the new industries, or the old manufacturing or burgeoning service industries" (Jamieson, 1989 , p. 71). In addition, as Halsey (1990, p. 96) has pointed out, "liberal cheerfulness concerning upgrading towards universal, middle-class professional society cannot plausibly accommodate the re-emergence of widespread unemployment in the First World capitalist countries ... [and] the growth of insecure, part-time and temporary jobs with precarious conditions of service as a conspicuous feature of modern free-enterprise economies". That kind of labour market dualism, I would add, has a national and international character, with the continued exportation of low-ability, low-wage jobs to economically and politically depressed groups and nations.

The second source for apprehension relates to the kind of vision that economistic discourse-be it of the utilitarian or emancipatory kind-generates in the field of education, and on the implications of this for the way teachers' work is conceptualised. The rest of the article is dedicated to an articulation of these dual and confluent concerns, and to specific strategies that should be considered if educators are to reclaim education.

\section{Defining Education}

The preoccupation with "performativity" (Lyotard, 1984) in the field of education has led to the predominance of what Habermas (summarised in Ewert, 1991) refers to as "instrumental rationality", where the criteria for establishing the best course of action is decided not with reference to the best reasons, but with reference to the most efficient 
and effective course to achieve desired ends. Instrumental, technocratic rationality has become all-pervasive and hegemonic, and it is primarily interested in "manipulation and control of the environment, in making predictions about observable physical or social events, in the definition of reality based on empirical knowledge and governed by technical rules, and in the effective control of reality, which determine the appropriateness of action" (Mezirow, 1981, p. 4, cited in Ewert, 1991, p. 348). Instrumental rational actions are "goal-directed, feedback-oriented interventions in a presumed objective world" (Ewert, 1991, p. 348). The problem, according to Habermas, is that this kind of rationality has colonised other life worlds, so that, as a result, moral, aesthetic, educational and political issues are reduced to technical problems, and value-based questions referring to the 'why' and the 'what' are reduced to technical questions referring to the 'how'.

This means that words like education, democracy and citizenship have become steeped in a technocratic rationality which "considers education primarily in instrumental terms and interprets democracy as a system of political management rather than a distinctive form of social and moral life. In such a culture, educational science is inevitably portrayed as quasi-technical expertise in which non-technical, non-expert questions about the moral and social purposes of education are virtually ignored" (Carr, 1989, p. 36). Carr in fact concludes that "the idea of an educational science as a form of democratic moral discourse now lacks the social context necessary for its practical application". The result of this is that education becomes a question of behaviour modification and competency based schooling, with an emphasis being placed on control, conformity and standardised curriculum packages. Educational success or failure becomes defined simply in terms of the results obtained in standardised test scores.

\section{Teachers' Work}

A logical extension of this form of rationality is the conceptualisation of teachers' work as a skilled craft based on technical expertise. As Bullough \& Goldstein have argued (1984, p. 146) "teaching [from the instrumental perspective] becomes the management of standardised ends and means; learning becomes the consumption of prepackaged bits of information and parts of skills; and success becomes teachers and students doing as directed".

Teachers' work is no longer considered as a moral activity with a deep commitment to an emancipatory value system, but rather as a technical activity, where a competent teacher is the one who is able effectively to implement the policies of the government of the day. Teaching is moral because, as Peters (1965) argued, it presupposes that something of value is to be taught. It is also moral because the relationship between the teacher and student is characterised by an imbalance of power, and that this power will be used to facilitate enlightenment and emancipation, rather than servitude and exploitation (Tom, 1980).

The conceptualisation of education as a moral project, and of the teacher as a transformative intellectual, is historically at the heart of the European educational tradition, and was revitalised in the period of the French Revolution by Condorcet (Michel, 1988), by Dewey in the early twentieth century, and by many of our direct mentors in the 1960s. This vision is in danger of being lost. In the current social climate, we witness the break-down of a consensus whose roots go deep into the past, reaching towards that Enlightenment dream which, we are told by the likes of Fukayama (1992), is over. We have lost the total vision of who we are, and seem to be able to focus only 
on the fragmented and fragmentary, targeting reforms at groups and categories of pupil without an overall "arch of social dreaming", a vision of where we are going.

Focusing for a moment on the European context, we can observe a massive challenge to the legitimacy of the teaching body to define internally the priorities and goals of the educational system (Neave, 1992, p. 9). This in itself need not necessarily be negative, and could, in its more progressive moments, lead to policy-making being carried out on a dialogic basis with many social partners. Indeed, of the two models of education that are emerging in contemporary Europe, one of these, what Vonk (1991) refers to as the professional approach, gives the highest premium to participant-involved educational planning, collaborative efforts, shared authority and responsibility among various educational bodies and the public. The image of the teacher here is that of a professional leader, immersed in and knowledgeable about and responsive to the needs of the community, but nevertheless a leader.

In many European countries, argues Vonk, however, the educational model that is being adopted is "bureaucratic-managerial", where education is arbitrary, imposed, and pedagogically defined, a bureaucratically structured delivery-system that results from political and economic debates rather than dialogues between interested parties. The image of the teacher is that of a technician in a minimum capacity model, where values of immediacy, practicality, relevance and utility reign supreme. In this context, "teachers' work is ... more and more strictly defined, more fragmented, more supervised, more assessed ... teachers are more and more losing control over [their own work]" (Vonk, 1991, p. 135). In other words, and utilising an umbrella term borrowed from Ball (1993), teachers' work has become subject to "overdetermination".

These trends at the macro level filter down to the micro worlds of the school and the classroom. As Ball (1993) has so perceptively pointed out, the introduction of market forces and management discourse in the field of education, generating such practices as open enrolments, parental choice, per-capita funding, and competition between schools, creates a new value context where "image and impression management are more important than the educational process" (p. 108). Ball's ethnographies present evidence that "the discourses of financial planning and economic rationalism [operate] in an antagonistic relation to the discourses of teaching and learning and pupil welfare" (p. 109), and that "for both parents, acting in the best interests of their children, and ... teachers, acting in the best interests of their school, the market leaves little alternative but to engage in individualistic, competitive activity" (p. 109). Gone, therefore, is the attempt to save the notion of the public sphere in the field of education. Here too, as in the market, shrewdness comes before principles. Here too, as in the market, reigns the culture of profit and production rather than the culture of welfare (Ball, 1993, p. 119).

Teachers everywhere are finding themselves, as a consequence, hemmed in and constrained by national curricula, national testing, interventions into pedagogical decision-making, so that, as Ball has noted, "there is an increase in the technical elements of teachers' work and a reduction in the professional ... [the] spaces for professional autonomy and judgement are reduced". In most policy-making processes, teachers are "an absent presence" (Ball, 1993, p. 107), talked about, with their work both as vocational practice and mental labour being redefined without consultation. The image of the teacher is one of deliverer, tester, technician. The teacher has, therefore, been effectively assigned to classroom teaching, and absolved from concern with the school as a social institution and with the social environment as the working space. As Mitter (1991, p. 143) has noted, teachers might be considered, in the present European climate, as change agents, but only on the Commission's own terms, and not as engaged in 
self-determined activities at the grass roots. These processes are visible not only with reference to teachers, but to other professions as well (Button \& Fleming, 1992).

The implications of this for the teacher are serious in other ways too. Not only is their work being routinised and proletarianised, not only are we losing control over such professional tasks as the articulation of an educational vision, the design of curricula, the establishment of a pedagogical tradition which is at least as concerned with moral issues as with utilitarian ones, not only is our claim that we possess expert knowledge being undermined. Further than that, the conditions of service too are deteriorating. Issues of pay, service conditions, and other bread and butter issues are related to what has been argued thus far, for, as Neave (1992, p. 11) correctly points out, they are crucial both for what they are and for what they represent, for they are "also vehicles of discourse through which other matters of symbolic significance are negotiated".

Reflecting on the teachers' plight in Europe, an OECD document (1985) refers to the "malaise" of teachers, with society expecting ever more of them in terms of the resolution of economic, social and cultural problems. "Few corps", notes Neave (1992, p. 2), in his study of teachers in the European Community, "bear so heavy a burden in the realm of social engineering, where rapid success is expected and where the inability to demonstrate it in the short run leads all too quickly to the conviction that absence of success is tantamount to failure". And yet, despite the pressure of the "anthropomorphisation" of the economic crisis on the teaching body (Neave, 1992, p. 9), teachers' salaries in most European nations have not increased sufficiently to make up for inflation, and there is a tendency for remuneration to decrease in comparison with that of other socio-professional categories (Andrieu, 1992, p. 112).

In addition to that, Neave points out to the development of a dual labour market in teaching in the European Union, with a peripheral market for those teaching humanities and social sciences, and central markets commanding higher salaries and better conditions of service for those teaching mathematics, science, technical education, physics, and computer science. With the European Union's policy favouring-indeed, actively promoting - a European mobile teacher, those teaching the latter subjects will be able to cross national boundaries, entering into direct competition with colleagues, and further fragmenting unity among the professional corps. There are other implications here, for, in the context of off-loading States, teachers are bound to experience a sea of change, as the shift from a buyers' market to a sellers' market will erode, if not completely destroy, their civil service status (Neave, 1992, pp. 129, 144).

\section{Conclusion: teachers reclaiming teaching}

The context has been set, and the problem described and located in regional and supra-national terms. Such reflection should lead to action, but what kind of action? First of all, this action must be articulated with reference to struggle, with a view of education which sees it as a site of contestation between different and conflicting interests. As has been noted above, it is from such a vision that we can generate not only self, group and social understanding, but also motivation to act. As educators, we are struggling against the further colonisation of life by a means-ends rationality. More pragmatically and less philosophically, we are watching out for the interests of those in our care which, after all, is our vocation. That struggle has to take place at a number of levels and in different sites. I would like to conclude this article by briefly mentioning some of these sites.

The first arena for struggle is the classroom, the school, and especially the relationship between these spaces and the community. Those of us on what can be broadly referred 
to as being on the humanist Left have developed an impressive arsenal here, including critical pedagogy, action research, reflective work with and among colleagues, parental involvement in education, and so on. All these facilitate the generation and sustenance of critical perspectives on schooling and society as well as commitments to work against the grain inside schools and the wider public sphere. The intensification of such grass-roots work based on the co-labour of learning communities will do much to create spaces where emancipatory discourse can flourish, and where people can develop visions for education that are potentially autonomous, undetermined by agendas set elsewhere.

One cannot overemphasise the importance of this kind of struggle. On the other hand, these kinds of micro-strategies governing the political work of educators, unsustained by a larger vision of what is taking place in the world today, will, by themselves, turn out to be too weak to carry us in the broader direction we have explored today. Microresponses might be comforting and attractive during this particular historical "postmodernist" conjuncture when it is so difficult to adopt "master" or even "grand" narratives (McLaren, 1988). But we, as educators, will risk winning battles and losing wars if we keep our nose too close to the ground, since by so doing we can be easily drawn on the ideological and political grounds provided by the wider institutional framework.

The article first addressed the theme of "globalisation" and "internationalisation". The focus on what is happening in the European Union developed this theme further, showing the ways in which policy-making in the field of education now crosses national frontiers. My contention is that educators' response to such developments should be no less international, and no less vigorous. We have to abandon sectarian approaches induced by the corporate strategies of the state, and which ultimately lead unionised workers such as ourselves into horizontal rather than vertical struggles. A reconstituted, militant body of teachers, which in Europe represents the "largest single concentration of highly qualified manpower in each and every Member state" (Neave, 1992, p. 1), alerted to what is at stake, and actively striving to develop and create alliances with other labouring groups, ought to claw back its right to formulate a vision for education. It ought not be satisfied with less.

\section{Acknowledgement}

I am indebted to the French Ministry of Education for awarding me a study grant to carry out research on Europe and education in various institutions in Paris, during the summer of 1992. I am especially grateful to Marguerite Michel-La Borderie, the Attaché Culturel, Scientifique et de Coopération at the French Embassy in Malta, through whose efforts funding was granted.

Correspondence: Ronald G. Sultana, Co-ordinator, Comparative Education Programme, Faculty of Education, University of Malta, Msida MSD 06, Malta.

\section{REFERENCES}

ANDERSON, B. (1982) Imagined Communities (London, Verso).

ANDrieu, M.J. (1992) L'Espace Educatif Europeen (Paris, Conseil Economique et Social).

BALL, S.J. (1993) Education policy, power relations and teachers' work, British Joumal of Educational Studies, 41 , pp. $106-121$. 
Bouchez, E. \& DE PERETT, A. (1990) Ecoles et Cultures en Europe (Paris, Savoir-Livre).

Brown, P. \& LAUdER, H. (1991) Education, economy and social change, International Studies in Sociology of Education, 1, pp. 3-23.

BRUCE, M. (1991) Internationalising teacher education, British Journal of Educational Studies, 39, pp. 163172.

Bullough, R.V. \& Goldstern, S.L. (1984) Technical curriculum form and American elementary-school art education, Journal of Curriculum Studies, 16, pp. 143-154.

ButTon, K. \& Fleming, M. (1992) The professions in the single European market: a case study of architects in the UK, Journal for Common Market Studies, 30, pp. 403-418.

Carnoy, M. \& Levin, H. (1985) Schooling and Work in the Democratic State (Stanford, Stanford University Press).

CARR, W. (1989) Action research: ten years on, Joumal of Curriculum Studies, 21, pp. 85-90.

EwERT, G.D. (1991) Habermas and education: a comprehensive overview of the influence of Habermas in educational literature, Review of Educational Research, 61, pp. 345-378.

Featherstone, M. (1991) Consumer Culture and Postmodernism (London, Sage).

Fukuyama, F. (1992) The End of History and the Last Man (New York, Free Press).

GidDEns, A. (1989) Sociology (Cambridge, Polity).

GutHrie, J.W. \& PIERCE, L.C. (1990) The international economy and national education reform: a comparison of education reforms in the United States and Great Britain, Oxford Review of Education, 16, pp. 179-205.

HAAHR, J.H. (1992) European integration and the Left in Britain and Denmark, Journal of Common Market Studies, 30, pp. 77-100.

HaLSEY, A.H. (1990) Educational systems and the economy, Current Sociology, 38(2/3), pp. 79-101.

Husen, T., Tuinam, A. \& Halls, W.D. (1992) Schooling in Modern European Society (Oxford, Pergamon Press).

JAMieson, I. (1989) Education and the economy: themes and issues, Journal of Education Policy, 4, pp. 69-73.

KurTh, J. (1993) Toward the postmodern world, Dialogue, 100(2), pp. 8-13.

LeClercQ, J.M. \& RaUlt, C. (1990) Les Systèmes Educatifs en Europe: Vers un Espace Communautaire? (Paris, La Documentation Francaise).

Levin, H. (1990) Economic trends shaping the future of teacher education, Educational Policy, 4, pp. 1-15.

LowE, J. (1992) Education and European integration, International Review of Education, 38, pp. 579-590.

LyotaRd, J.F. (1979) The Postmodern Condition: a report on Knowledge (Minneapolis, University of Minneapolis Press).

MCLAREN, P. (1988) Schooling and the post-modern body: critical pedagogy and the politics of enfleshment, Joumal of Education (Boston), 170(3), pp. 53-83.

Michel, C. (1989) 1789-1989: the French revolution: have the revolution's educational demands been implemented?, Teachers of the World (Berlin, FISE).

MrTter, W. (1991) Teacher education in Europe: problems, challenges, perspectives, British Journal of Educational Studies, 39, pp. 138-152.

NEAvE, G. (1992) The Teaching Nation: prospects for teachers in the European Community (Oxford, Pergamon Press).

OZGA, J. \& LAWN, M. (1988) Schoolwork: interpreting the labour process of teaching, British Joumal of Sociology of Education, 9, pp. 323-336.

Peters, R.S. (1968) Must an educator have an aim?, in: C. B. J. MACMILlan \& T. W. Nelson (Eds) Concepts of Teaching (Chicago, Rand McNally).

PRATZNER, F. (1985) The vocational education paradigm: adjustment, replacement and extinction, Journal of Industrial Teacher Education, 22, pp. 15-25.

RAMSAY, H. (1992) Whose champions? Multinationals, labour and industry policy in the European Community after 1992, Capital and Class, 48, pp. 17-39.

Ross, G. (1992) Confronting the new Europe, New Left Review, 191, pp. 49-68.

SHARP, R. (1988) Old and new orthodoxies: the seductions of liberalism, in: M. COLE (Ed.) Bowles and Gintis Revisited (Lewes, Falmer Press).

SultanA, R.G. (1992) Education and National Development: historical and critical perspectives on vocational schooling in Malta (Msida, Mireva).

Tom, A.R. (1980) Teaching as a moral craft: a metaphor for teaching and teacher education, Curriculum Inquiry, 10(3), pp. 19-28.

VAniscotte, F. (1989) 70 Millions d'Elèves: l'Europe de l'education (Paris, Hatier).

VIOLAS, P.C. (1981) Reflections on theories of human capital, skills training and vocational education, Educational Theory, 31, pp. 137-151. 
VONK, H. (1991) Some trends in the development of curricula for the professional preparation of primary and secondary school teachers in Europe: a comparative study, British Journal of Educational Studies, 39, pp. $117-137$.

Watson, K. (1991) Teachers and teaching in an interdependent world, Compare, 21, pp. 107-126. 